\title{
Effects of drying methods on quality characteristics and antioxidative effects of Omija (Schizandra chinesis bailon)
}

\author{
Seul Lee ${ }^{1}$, Hey-Kyung Moon ${ }^{2}$, Su-Won Lee ${ }^{3}$, Jae-Nam Moon ${ }^{1}$, Jong-Kuk Kim ${ }^{1} *$ \\ ${ }^{1}$ Department of Food and Food-Service Industry, Kyungpook National University, Sangju 742-711, Korea \\ ${ }^{2}$ Center for Scientific Instruments, Kyungpook National University, Sangju 742-711, Korea \\ ${ }^{3}$ Tory Food Company, Sangju 742-821, Korea
}

\section{건조방법을 달리한 오미자의 품질특성 및 항산화 효과}

\author{
이슬 ${ }^{1} \cdot$ 문혜경 $^{2} \cdot$ 이수원 ${ }^{3} \cdot$ 문재남 $^{1} \cdot$ 김종국 $^{1} *$ \\ ${ }^{1}$ 경북대학교 식품외식산업학과, ${ }^{2}$ 경북대학교 공동실험실습관, ${ }^{3}$ (주)토리식품
}

\begin{abstract}
The antioxidative effect and quality characteristics of different drying methods (hot air drying, far-infrared radiation drying, vacuum freeze drying) from Schizandra Chinensis Baillon were investigated. The moisture contents and water activity(Aw) contents each $4.46 \%$ and 0.38 values of the vacuum freeze drying were lower than those of other samples. A significant not difference in $\mathrm{pH}$ values occurred in all samples $(\mathbf{p}<0.05)$. The highest content ${ }^{\circ}$ brix vacuum freeze drying was $6.60{ }^{\circ}$ Brix respectively. The turbidity values of the samples were hot air drying $8.24 \mathrm{~T} \%$ far infrared radiation drying $0.32 \mathrm{~T} \%$ vacuum freeze drying $71.85 \mathrm{~T} \%$ The Hunter's $\mathrm{L}$, a and b values of vacuum freeze drying were higher than those of other samples. The order of the free sugar content was glucose $>$ fructose $>$ sucrose, and that of the total free sugar contents were vacuum freeze drying $(6.33 \mathrm{~g} / 100 \mathrm{~g})>$ far infrared drying $(5.01 \mathrm{~g} / 100 \mathrm{~g})>$ hot air drying $(3.73 \mathrm{~g} / 100 \mathrm{~g})$. Antioxidant acitivy (DPPH radical scavenging, ABTS radical scavenging) and total phenol, total flavonoid, and total tannin content was highest in vaccum freeze drying than other different drying methods except nitrite scavenging ability.
\end{abstract}

Key words : dried Omija (Schizandra chinesis Baillon) fruits, drying methods, quality characteristics, antioxidant

\section{서 론}

오미자(Schizandra chinensis B.)는 목련과에 속하는 상록 성 덩굴식물로 품종과 재배환경에 따라 다소 차이가 있지만 단맛, 신맛, 쓴맛, 매운맛, 짠맛의 다섯 가지 맛을 내며 안토 시아닌에 의해 선명한 붉은색을 나타내는 것이 특징이다. 오미자의 과육에는 탄수화물, 종자에는 $\mathrm{K}, \mathrm{Mn}$ 및 $\mathrm{Ca}$ 이 많 이 함유되어 있으며, 특히 열매는 알콜 해독 작용 및 항산화 작용이 뛰어난 것으로 보고되어 있다(1,2). 오미자는 예로 부터 한방에서 진정, 진해, 해열제 등으로 이용되었으며, 알코올 해독, 혈당 강하, 콜레스테롤 저하, 면역 조절, 항암 및 항종양 등 다양한 생리활성을 가지는 것으로 보고되고

*Corresponding author. E-mail : kjk@knu.ac.kr

Phone : 82-54-530-1305, Fax : 82-54-530-1309
있으며 $(3,4)$, 주성분은 리그난(lignan) 화합물이며 palmitic acid와 stearic acid 등의 지방산과 유기산 등을 함유하고 있으며(5), schizandrin, schizadran, $\gamma$-schizadrin, ethamigrenal, gomisin류 등의 성분이 보고된 바 있다(6).

오미자는 크게 생 오미자, 냉동 오미자, 건조 오미자 등으 로 유통되며, 건조 오미자는 주로 열풍 건조 $\left(50 \sim 80^{\circ} \mathrm{C}\right)$ 에 의해 제조된다(7). 열풍건조는 열풍으로 제품 전체를 가열 하여야 하므로 열효율이 낮고, 가열로 인한 제품의 향기성 분이나 비타민 또는 유용한 무기질 등이 파괴되어 많은 영양적 손실과 함께 수분손실에 기인된 수축현상, 표면경 화, 낮은 복원력 등의 문제점이 있다(8). 진공건조 방식은 색조, 풍미, 복원성 등이 우수하며, 재료의 함수율이 높을 때 낮은 온도에서 건조할 수 있는 특징이 있어 고품질 농산 물을 건조하는데 많이 쓰이고 있다(9). 원적외선을 이용한 건조법은 열원에서 나온 전자파가 대상물질에 직접 도달하 
므로 천일건조와는 달리 건조시간의 단축이 가능하고, 영 양성분의 파괴나 변형이 없어 고품질의 농산물가공에 적절 한 기술이라 할 수 있다(10).

건조 오미자와 관련된 연구로는 건조 오미자의 추출조건 과 관련된 연구(7,11), 저장 중 품질변화(12), 건조 및 추출방 법에 따른 오미자 휘발성 성분의 변화(13) 등이 보고되고 있으나 건조 방법에 따른 오미자의 품질특성과 항산화 효과 를 비교한 연구는 아직 미미한 수준이다.

오미자는 다양한 생리활성을 함유하고 있음에도 이를 최대한으로 발현시킬 수 있는 건조 방법에 관한 연구는 아직 활발히 이루어지지 않고 있어 향후 이에 관한 연구가 필요할 것으로 생각된다.

이에 본 연구에서는 열풍건조, 원적외선 건조, 동결건조 한 오미자의 품질특성 및 항산화 효과를 비교 검토하여 고품질의 건조 오미자의 최적 건조 방법을 찾고자 하였다.

\section{재료 및 방법}

\section{실험재료}

오미자는 시중에서 판매중인 열풍건조 오미자(문경건오 미자, 2012년산)와 원적외선건조 오미자(문경원적외선건 오미자, 2012년산)는 문경 산동농협에서 구입하여 분석용 시료로 사용하였고, 진공동결건조 오미자는 문경 농가에서 2012년 9월 20일 수확한 오미자를 구입하여 진공동결건조 기(SFDTS-10K, Samwon Engineering, Pusan, Korea)를 이용 하여 진공동결건조한 오미자를 분석용 시료로 사용하였다.

시중에서 구입한 건조오미자와 진공동결건조 오미자는 믹서기(HR-2860/55, Philips Electronics Ltd, Seoul, Korea)로 60 초간 분쇄한 후 분석용 시료로 사용하였다.

\section{수분 함량 및 수분활성도 측정}

건조방법을 달리한 오미자의 수분 함량은 건조오미자를 $\mathrm{AOAC}$ 방법(14)에 준하여 상압 가열건조법을 이용하였고, 수분활성은 건조오미자를 수분활성도 측정기(HP23-AW, Rotronic, Bassersdorf, Switzerland)를 이용하여 3회 반복 측 정하여 평균값으로 나타내었다.

\section{$\mathrm{pH}$, 당도 및 탁도 측정}

건조방법을 달리한 오미자의 $\mathrm{pH}$ 측정은 건조 오미자 시 료를 $5 \mathrm{~g}$ 취하여 $50 \mathrm{~mL}$ 의 증류수를 가한 후 $20^{\circ} \mathrm{C}$ 에서 2 시간 추출한 다음 Whatman No. 5 여과지를 이용하여 여과한 액을 $\mathrm{pH}$ meter(691 pH Meter, Metrohm, Herisau, Switzerland)로 3회 반복 측정하여 평균값으로 나타내었다. 당도 측정은 건조 오미자 시료를 $5 \mathrm{~g}$ 취하여 $50 \mathrm{~mL}$ 의 증류수를 가한 후 $20^{\circ} \mathrm{C}$ 에서 2시간 추출한 후 Whatman No. 5(Whatman plc, Kent, UK) 여과지를 이용하여 여과한 액을
굴절당도계(N-1E, Atago, Tokyo, Japan)로 3회 반복 측정하 여 평균값으로 나타내었다.

탁도 측정은 건조 오미자 시료를 $5 \mathrm{~g}$ 취하여 $50 \mathrm{~mL}$ 의 증류수를 가한 후 $20^{\circ} \mathrm{C}$ 에서 2 시간 추출한 후 Whatman No. 5 여과지를 이용하여 여과한 액을 UV-Visible spectrophotometer (UV Spectrophotometer 1601, Shimadzu, Kyoto, Japan)를 사용하여 $660 \mathrm{~nm}$ 에서 3회 반복 측정하여 평균값으로 나타 내었다.

색도 측정

건조방법을 달리한 오미자의 색도 측정은 건조 오미자 표면을 색차계(Spectrocolorimeter, USXE/SAV/UV-2, Hunterlab Overseas Ltd., Reston, VA, USA)를 이용하여 명도(L-value, lightness), 적색도(a-value, redness) 및 황색도(b-value, yellowness) 값을 3 회 반복 측정하여 평균값으로 나타내었 다. 이때의 표준 백색판 $(\mathrm{L}=99.11, \mathrm{a}=0.23, \mathrm{~b}=-0.28)$ 을 사용 하였다.

\section{유리당 함량 측정}

유리당은 Wilson과 Work 방법(15)에 따라 시료를 약 5 $\mathrm{g}$ 씩 정확히 칭량하여 $80 \%$ 에탄올 용액 $100 \mathrm{~mL}$ 를 가하여 환류 냉각 추출 장치에 넣어 부착된 heating mantle에서 $80^{\circ} \mathrm{C}, 2$ 시간 동안 당 성분을 반복 추출 후 Whatman No. 5 로 여과한 여액을 진공 농축 건조 $\left(40^{\circ} \mathrm{C}\right)$ 후 증류수 $5 \mathrm{~mL}$ 로 정용한 다음 $0.45 \mu \mathrm{m}$ membrane filter로 여과한 후 HPLC(Waters 2695, Waters Co., Milford, Massachusetts, USA)로 분석하였다. 이때 column은 carbohydrate column(ID $3.96 \times 300 \mathrm{~mm}$, Waters Co., Milford, Massachusetts, USA), column oven 온도 $35^{\circ} \mathrm{C}$, mobile phase $75 \%$ acetonitrile, flow rate $1.0 \mathrm{~mL} / \mathrm{min}$, 시료 주입량 $10 \mu \mathrm{L}$ 의 조건으로 Refractive Index(RI) detector(Waters 2414, Waters Co., Milford, MA, $\mathrm{USA}$ )에서 검출하였다. 표준품은 xylose, fructose, glucose, sucrose, arabinose, maltose, mannose 및 lactose(Sigma, St. Louis, MO, USA)를 일정량씩 혼합하여 증류수에 녹여 표준 용액으로 사용하였다. 표준품과 시료의 당 성분은 머무른 시간(Rt)을 직접 비교하여 확인하였고, 각 표준품의 검량 곡선을 작성하여 peak의 면적으로 개별 당 성분의 함량을 산출하였다.

\section{시료의 추출}

건조방법을 달리한 오미자의 항산화 성분 함량 및 활성 을 비교하기 위하여 시료 $5 \mathrm{~g}$ 에 $80 \%$ 에탄올 용액 $100 \mathrm{~mL}$ 를 가하여 환류냉각기가 부착된 heating mantle에서 $80^{\circ} \mathrm{C}, 3$ 시 간 반복추출 후 Whatman No. 5(Whatman plc, Kent, UK)로 여과하였다. 여과액은 $50^{\circ} \mathrm{C}$ 진공농축 건고 후 3 차 증류수 $10 \mathrm{~mL}$ 로 정용하였다. 


\section{$\mathrm{DPPH}$ 에 의한 전자공여능의 측정}

$\mathrm{DPPH}(a, a-d i p h e n y l-\beta$-picrylhydrazyl) radical 소거활성은 Blios의 방법(16)에 준하여 변형하여 측정하였다. 각 추출물 $0.2 \mathrm{~mL}$ 에 $0.4 \mathrm{mM} \mathrm{DPPH} 0.8 \mathrm{~mL}$ 를 넣고 vortex한 후 10 분 동안 암소에 방치한 다음 $525 \mathrm{~nm}$ 에서 흡광도를 측정하여 다음 식에 의하여 나타내었다.

$\mathrm{DPPH}$ radical 전자공여능 $(\%)=\left(1-\frac{\text { 시료 첨가구의 } O D}{\text { 시료 무첨가구의 } O D}\right) \times 100$

\section{$\mathrm{ABTS}$ 라디칼 소거능 측정}

ABTS 라디칼 소거능은 Kriengsak 등(17)의 방법을 변형 하여 측정하였다. $7.4 \mathrm{mM} \mathrm{ABTS}$ 용액에 $2.6 \mathrm{mM}$ potassium persulfate를 동량으로 혼합하여 암소에서 약 24시간 반응시 킨 후 ABTS free radical이 생성된 ABTS 용액을 $99.9 \%$ ethanol로 희석하여 $734 \mathrm{~nm}$ 에서 흡광도 값이 $1.5 \pm 0.1$ 가 되 도록 조절하였다. ABTS radical이 생성된 ABTS 용액 2.7 $\mathrm{mL}$ 와 시료 $0.3 \mathrm{~mL}$ 를 혼합하여 7분간 반응시킨 후 700 $\mathrm{nm}$ 에서 흡광도를 측정하였다. 결과 값은 아래의 식에 의해 나타내었다.

$\mathrm{ABTS}$ radical scavenging activity $(\%)=\left(1-\frac{\text { 시료 첨가구의 } O D}{\text { 시료 무첨가구의 } O D}\right) \times 100$

\section{아질산염 소거능}

아질산염 소거능은 Kato 등(18)의 방법을 변형하여 측정 하였다. $1 \mathrm{mM} \mathrm{NaNO}$ 용액 $1 \mathrm{~mL}$ 에 시료 $1 \mathrm{~mL}$ 를 가하고 $0.1 \mathrm{~N} \mathrm{HCl}$ 로 반응용액의 $\mathrm{pH}$ 를 1.2 로 조정한 후 전체량을 $10 \mathrm{~mL}$ 로 만들어 이 용액을 $37^{\circ} \mathrm{C}$ 에서 1 시간 동안 반응시켰 다. 반응액 $1 \mathrm{~mL}$ 에 Griess 시약 $(1 \%$ sulfanilic acid: $1 \%$ naphthylamine=1:1) $0.4 \mathrm{~mL}, 2 \%$ acetic acid $5 \mathrm{~mL}$ 를 혼합시켜 15 분간 실온에 방치시킨 후, $520 \mathrm{~nm}$ 에서 흡광도를 측정하 였다. 아질산염 소거작용은 시료를 첨가한 경우와 첨가하 지 않은 경우를 백분율로 나타내었다.

Nitrite scavenging ability $(\%)=\left(1-\frac{\text { 시료 첨가구의 } O D}{\text { 시료무첨가구의 } O D}\right) \times 100$

\section{총 페놀 함량 측정}

총 페놀 화합물은 Folin-Denis법(19)으로 측정하였다. 각 시료 추출물 $1 \mathrm{~mL}$ 에 Folin-Denis시약 $0.2 \mathrm{~mL}$ 및 $2 \% \mathrm{Na}_{2} \mathrm{CO}_{3}$ 용액 $2 \mathrm{~mL}$ 를 가하여 혼합하고 실온에서 30 분간 정치시킨 후 $700 \mathrm{~nm}$ 에서 흡광도를 측정하였다. 이때 표준검량곡선은 garlic acid(Sigma)를 이용하여 작성하였다.

\section{총 플라보노이드 함량}

각 추출물 $0.5 \mathrm{~mL}$, diethylene glycol(Daejung Chemicals \& Metals CO., LTD., Siheung, Korea) $5 \mathrm{~mL}, 1 \mathrm{~N} \mathrm{NaOH}$ $0.5 \mathrm{~mL}$ 을 첨가한 다음 혼합하여 $30^{\circ} \mathrm{C}$ 의 항온수조(VS-
190CS, Vision Sci., Korea)에서 1시간 반응시킨 후 $420 \mathrm{~nm}$ 에서 흡광도를 측정하였다(20). Quercetin(Sigma)을 표준물 질로 검량선을 작성한 후 플라보노이드 함량을 정량하였 다.

\section{총 탄닌 함량}

총 탄닌 함량은 Urve 등(21)의 방법을 변형하여 측정하였 다. 각 추출물 $0.5 \mathrm{~mL}$ 에 $1 \% \mathrm{~K}_{3} \mathrm{~F}_{3}(\mathrm{CN})_{6} 1 \mathrm{~mL}$ 와 $1 \% \mathrm{FeCl}_{3}$ $1 \mathrm{~mL}$ 를 첨가한 다음 혼합하여 5 분 후 $720 \mathrm{~nm}$ 에서 흡광도를 측정하였다. Tannin acid(Samchun pure chemical Co,, Pyeongtaek, Korea)를 표준물질로 검량선을 작성한 후 탄닌 함량을 정량하였다.

\section{통계처리}

본 실험에 대한 결과는 평균과 표준편차로 나타내었고, Statistical Analysis System(SAS, Version 9.2, Cary, NC, USA)을 이용하여ANOVA 분석을 실시한 후, Duncan's multiple range test로 $p<0.05$ 수준에서 유의차 검정을 실시하 였다.

\section{결과 및 고찰}

\section{수분 및 수분활성도}

건조 방법을 달리한 오미자의 수분 및 수분활성도 측정 결과는 Table 1 과 같다. 수분 함량은 건조 방법에 따라 열풍 건조 오미자 $7.41 \%$ 로 가장 높았고, 원적외선건조 오미자 $6.66 \%$, 진공동결건조 오미자 $4.46 \%$ 순으로 나타나 진공동 결건조가 건조율이 가장 좋은 것으로 생각된다. Jung 등(22) 의 보고에서는 열풍건조 오미자 $1.47 \%$, 동결건조 오미자 $2.02 \%$ 로 보고하여 본 실험과는 상이한 결과를 나타내었다. $\mathrm{Kim}$ 등(23)은 열풍건조 구기자 $22.30 \pm 1.11$, 동결건조 오미 자 $18.93 \pm 0.71$ 로 보고하여 본 실험 결과와 유사한 경향을 나타내었다. 이는 건조방법은 같으나 건조조건, 시료 보관 방법 등이 달라 나타난 결과로 생각된다.

수분활성도(Aw)는 열풍건조 오미자 0.51 , 원적외선건조 오미자 0.45 , 진공동결건조 오미자 0.38 로 나타났다. 미생물 의 성장 및 증식에는 일정량 이상의 수분이 필요하며, 수분

Table 1. Moisture and water activity of different dry condition of Omija (Schizandra chinesis Bailon)

\begin{tabular}{ccc}
\hline Sample & Moisture (\%) & Water Activity (Aw) \\
\hline Hot-air drying & $7.41 \pm 0.53^{1) \mathrm{a}}$ & $0.51 \pm 0.02^{\mathrm{a}}$ \\
Far-infrared radiation drying & $6.66 \pm 0.37^{\mathrm{b}}$ & $0.45 \pm 0.01^{\mathrm{b}}$ \\
Vacuum freeze drying & $4.46 \pm 0.49^{\mathrm{c}}$ & $0.38 \pm 0.01^{\mathrm{c}}$ \\
\hline
\end{tabular}

${ }^{1)}$ Quoted values are the mean \pm standard deviation of triplicate experiments.

${ }^{a-c}$ Values with different superscripts in a row are significantly different $(\mathrm{p}<0.05)$. 
활성도는 미생물의 성장과 증식에 큰 영향을 미치는 것으로 알려져 있다(24). 일반적으로 보통 세균이 자랄 수 있는 최저한의 수분활성도는 0.91 이며 효모와 곰팡이의 최저한 의 생육 수분활성도는 각각 $0.88,0.80$ 이다. 한편 내건성 곰팡이는 0.65 정도의 수분활성에서도 성장이 가능하며, 내삼투압성 효모는 0.60 정도의 수분활성도에서도 성장이 가능하다(25). 본 실험에서는 모두 0.60 미만의 수분활성도 를 나타내어 미생물의 성장 및 증식 예방이 가능하며, 그 중에서도 진공동결건조가 가장 효과적일 것으로 생각된다.

\section{$\mathrm{pH}$, 당도 및 탁도}

건조 방법을 달리한 오미자의 $\mathrm{pH}$, 당도 및 탁도 측정 결과는 Table 2 와 같다. $\mathrm{pH}$ 는 열풍건조 오미자 3.15 , 원적외 선건조 오미자 3.09 , 진공동결건조 오미자 3.11로 나타나 건조방법은 $\mathrm{pH}$ 값에 큰 영향을 미치지 않는 것으로 생각된 다. Jung 등(22)은 열풍건조 오미자는 2.78, 동결건조 오미자 는 2.74 로 보고하여 본 실험의 결과와 유사한 경향을 나타내 었다.

당도는 열풍건조 오미자 $4.63{ }^{\circ} \mathrm{Brix}$, 원적외선건조 오미 자 $5.42{ }^{\circ} \mathrm{Brix}$, 진공동결건조 오미자 $6.60{ }^{\circ} \mathrm{Brix}$ 를 나타내었 다. 당도는 진공동결건조한 것이 열풍건조, 원적외선건조 보다 높게 나타났는데 이는 Kim 등(26)의 연구에서 감말랭 이의 수분함량이 높을수록 가용성 고형분 함량이 낮고, 수 분함량이 낮을수록 가용성 고형분 함량이 높아졌다는 연구 와 유사하였다.

탁도는 증류수 $100 \mathrm{~T} \%$ 를 기준으로, 열풍건조 오미자 $8.24 \mathrm{~T} \%$, 원적외선건조 오미자 $0.32 \mathrm{~T} \%$, 진공동결건조 오 미자 $71.85 \mathrm{~T} \%$ 를 나타내었다. 열풍건조와 원적외선건조된 오미자의 경우 진공동결건조에 비해 $\mathrm{T} \%$ 값이 많이 낮은 값을 보였는데, 이는 열풍건조와 원적외선건조의 경우 고 온에 장시간 노출되면서 열에 의한 갈변이 촉진되어 $\mathrm{T} \%$ 값이 낮게 나온 것으로 생각된다.

Table 2. $\mathrm{pH}$, soluble solid and turbidity of different dry condition of Omija (Schizandra chinesis Bailon)

\begin{tabular}{cccc}
\hline Sample & $\mathrm{pH}$ & $\begin{array}{c}\text { Soluble solid } \\
\left({ }^{\circ} \text { Brix }\right)\end{array}$ & Turbidity (T\%) \\
\hline Hot-air drying & $3.15 \pm 0.01^{1) \mathrm{a}}$ & $4.63 \pm 0.02^{\mathrm{c}}$ & $8.24 \pm 1.23^{\mathrm{b}}$ \\
Far-infrared radiation drying & $3.09 \pm 0.01^{\mathrm{b}}$ & $5.42 \pm 0.01^{\mathrm{b}}$ & $0.32 \pm 0.04^{\mathrm{c}}$ \\
Vacuum freeze drying & $3.11 \pm 0.02^{\mathrm{b}}$ & $6.60 \pm 0.01^{\mathrm{a}}$ & $71.85 \pm 4.76^{\mathrm{a}}$ \\
\hline
\end{tabular}

${ }^{1)}$ Quoted values are the mean \pm standard deviation of triplicate experiments.

${ }^{\mathrm{a} C} \mathrm{~V}$ alues with different superscripts in a row are significantly different $(\mathrm{p}<0.05)$.

\section{색 도}

건조 방법을 달리한 오미자의 색도 $\mathrm{L}, \mathrm{a}, \mathrm{b}$ 값을 Table 3 에 나타내었다. 명도를 나타내는 L값은 진공동결건조 오 미자 33.76 로 가장 높은 값을 나나태었고, 원적외선건조
오미자 26.14, 열풍건조 오미자 25.40순으로 나타내었다. 적색도인 $\mathrm{a}$ 값은 열풍건조 오미자 13.08 , 원적외선건조 오미 자 20.30, 진공동결건조 오미자 37.94 를 나타났고, 진공동결 건조 오미자가 열풍건조 오미자에 비하여는 2.9 배, 원적외 선건조 오미자에 비해 1.8 배 높은 값을 나타내어 진공동결 건조 오미자는 안토시아닌 파괴가 적게 일어난 것으로 생각 된다. 황색도 $\mathrm{b}$ 값은 열풍건조 오미자 10.31 로 가장 낮은 값을 나타내었고, 원적외선건조 오미자 11.63 , 진공동결건 조 오미자 14.83 을 나타내었다. 건조방법에 따른 오미자의 색변화는 $\mathrm{L}, \mathrm{a}, \mathrm{b}$ 값이 전체적으로 동결건조한 시료에서 가장 높았다는 연구 보고(27)와 동일한 결과를 나타내었다. 그리고 열풍건조는 다른 건조방법과 비교하였을 때 $\mathrm{L}, \mathrm{a}$, $\mathrm{b}$ 값이 낮게 나타났는데, 이는 동결건조, 진공건조와 $\mathrm{L}, \mathrm{a}$, $\mathrm{b}$ 값을 비교할 때 열에 의한 손실로 인해 많은 변화가 일어난 다는 Yang과 Atallah의 보고(28)와 유사하였다. Jung 등(22) 은 건조방법에 따른 오미자의 색도 측정 결과 동결건조에서 L 22.57, a 20.78, b 6.05로 열풍건조, 천일건조에 비해 월등 히 높은 수치를 보였다고 보고하여 본 실험 결과와 유사한 경향을 나타내었다.

Table 3. Hunter's color values in different dry condition of Omija (Schizandra chinesis Bailon)

\begin{tabular}{|c|c|c|c|}
\hline \multirow{2}{*}{ Sample } & \multicolumn{3}{|c|}{ Color value $^{1)}$} \\
\hline & L (Lightness) & a (Redness) & $\mathrm{b}$ (Yellowness) \\
\hline Hot-air drying & $25.40 \pm 1.57^{2)^{b}}$ & $13.08 \pm 0.76^{\mathrm{c}}$ & $10.31 \pm 1.10^{b}$ \\
\hline Far-infrared radiation drying & $26.14 \pm 2.01^{b}$ & $20.30 \pm 1.31^{b}$ & $11.63 \pm 0.79^{b}$ \\
\hline Vacuum freeze drying & $33.76 \pm 2.85^{\mathrm{a}}$ & $37.94 \pm 1.90^{\mathrm{a}}$ & $14.83 \pm 1.26^{\mathrm{a}}$ \\
\hline
\end{tabular}

\section{유리당 함량}

건조 방법을 달리한 오미자의 유리당 함량은 Table 4에 나타내었다. 유리당 함량은 glucose $>$ fructose $>$ sucrose 순으로 나타났다. 총 유리당 함량은 원적외선건조가 6.33 $\mathrm{g} / 100 \mathrm{~g}$ 으로 가장 높게 나타났고, 진공동결건조 $5.01 \mathrm{~g} / 100$ $\mathrm{g}$, 열풍건조 $3.73 \mathrm{~g} / 100 \mathrm{~g}$ 순으로 나타났다. Furctose 함량은 원적외선건조 $3.00 \mathrm{~g} / 100 \mathrm{~g}$ 으로 가장 높았고, 진공동결건조 $2.02 \mathrm{~g} / 100 \mathrm{~g}$, 열풍건조 $1.48 \mathrm{~g} / 100 \mathrm{~g}$ 순으로 나타났다. Glucose 함량은 원적외선건조 $3.19 \mathrm{~g} / 100 \mathrm{~g}$, 열풍건조 2.23 $\mathrm{g} / 100 \mathrm{~g}$, 진공동결건조 $2.19 \mathrm{~g} / 100 \mathrm{~g}$ 순으로 나타났다. Sucrose 함량은 원적외선건조 $0.13 \mathrm{~g} / 100 \mathrm{~g}$, 진공동결건조 $0.80 \mathrm{~g} / 100 \mathrm{~g}$, 열풍건조 $0.01 \mathrm{~g} / 100 \mathrm{~g}$ 순으로 나타났다. Kim 등(29)은 오미자 추출물의 유리당 함량 측정결과 glucose $3.65 \sim 4.71 \%$, fructose 1.24 4.42\%, sucrose 0.89 1.69\% 순으 로 나타나 본 실험과 함량에 차이는 있었으나, 유사한 경향 
을 나타내었다. 이러한 결과의 차이는 시료 처리와 과실 숙성에 따른 차이에 기인한 것으로 생각된다.

Table 4. The free sugar composition of different dry condition of Omija (Schizandra chinesis Bailon)

\begin{tabular}{ccccc}
\hline \multirow{2}{*}{ Sample } & \multicolumn{4}{c}{ Free Sugar $(\mathrm{g} / 100 \mathrm{~g})$} \\
\cline { 2 - 5 } & Fructose & Glucose & Sucrose & total \\
\hline Hot-air drying & $1.48^{1)}$ & 2.33 & 0.01 & 3.73 \\
Far-infrared radiation drying & 3.00 & 3.19 & 0.13 & 6.33 \\
Vacuum freeze drying & 2.02 & 2.19 & 0.80 & 5.01 \\
\hline
\end{tabular}

${ }^{1)}$ Qutoted values the averages of duplicate measurements.

\section{$\mathrm{DPPH}$ 에 의한 전자공여능}

$\mathrm{DPPH}$ 는 화학적으로 유도되는 비교적 안정한 radical로 서 항산화제, 방향족 아민류 등에 의한 전자 공여에 의해 지질 과산화 연쇄반응에 관여하는 산화성 자유라디칼의 억제 정도를 측정하는 방법으로 어떠한 반응계에서 전자를 공여 받으면 고유의 자색이 탈색되어 색이 엷어진다 (30,31).

건조방법을 달리한 오미자의 DPPH radical의 소거능은 진공동결건조 오미자가 $88.68 \%$ 로 가장 높은 활성을 나타내 었으며, 다음으로 원적외선건조 오미자 $77.32 \%$, 열풍건조 오미자 $71.44 \%$ 순으로 나타났다(Table 5).

$\mathrm{Kim}$ 과 Choi(32)의 오미자 물 추출물의 DPPH radical 소 거능은 $100 ~ 1,000 \mu \mathrm{g} / \mathrm{m} l$ 의 농도에서 $49.6 ~ 72.4 \%$ 라고 보고 하여 본 실험결과에 비해 낮은 값을 나타내었고, Cho 등(33) 의 연구에서는 오미자 물 추출물과 $60 \%$ 에탄올 추출물에서 각각 $97.5 \%, 96.2 \%$ 의 소거활성을 나타내어 본 실험 결과에 비해 높은 값을 나타내었다. 이는 추출 용매와 농도 차이에 의한 것으로 생각된다.

Chang과 $\operatorname{Kim}(34)$ 은 항산화활성은 가열처리했을 경우 비 타민 $\mathrm{C}$ 와 같이 열에 약한 항산화물질이 파괴됨으로써 일반 적으로 그 효능이 감소된다고 하였는데, 본 실험에서도 열 처리된 열풍건조 오미자에 비해 진공동결건조 오미자의 항산화 활성이 상대적으로 높게 나타났다. Park 등(7)의 연

Table 5. DPPH radical scavenging activity, ABTS radical scavenging activity and nitrite scavenging ability of different dry condition of Omija (Schizandra chinesis Bailon)

\begin{tabular}{cccc}
\hline Sample & $\begin{array}{c}\text { DPPH radical } \\
\text { scavenging } \\
\text { activity (\%) }\end{array}$ & $\begin{array}{c}\text { ABTS radical } \\
\text { scavenging } \\
\text { activity (\%) }\end{array}$ & $\begin{array}{c}\text { Nitrite } \\
\text { scavenging } \\
\text { ability (\%) }\end{array}$ \\
\hline Hot-air drying & $71.44 \pm 3.66^{\mathrm{c}}$ & $85.91 \pm 0.75^{\mathrm{c}}$ & $88.78 \pm 1.50^{\mathrm{a}}$ \\
Far-infrared radiation drying & $77.32 \pm 2.91^{\mathrm{b}}$ & $87.92 \pm 0.61^{\mathrm{b}}$ & $90.04 \pm 0.61^{\mathrm{a}}$ \\
Vacuum freeze drying & $88.68 \pm 0.24^{1) \mathrm{a}}$ & $93.85 \pm 0.75^{1) \mathrm{a}}$ & $82.58 \pm 1.11^{1) \mathrm{b}}$ \\
\hline${ }^{1)}$ Quoted values are the mean \pm standard deviation of triplicate experiments. \\
${ }^{\mathrm{a} c}$ Values with different superscripts in a row are significantly different $(\mathrm{p}<0.05)$.
\end{tabular}

구에서도 건조방법에 따른 오미자의 항산화능은 동결건조 된 오미자가 열풍건조된 오미자보다 높게 나타났다고 보고 된 바 있다.

\section{ABTS radical 소거능}

ABTS 유리기 소거법은 극성과 비극성 시료의 소거 활성 을 모두 측정 할 수 있으므로 $\mathrm{DPPH}$ 유리기 소거법보다 적용 범위가 넓다(35). 또한 DPPH는 free radical, ABTS는 cation 유리기이므로 기질의 특성이 서로 다르다. 추출물의 특성에 따라 자유 라디칼과 cation 유리기와의 결합 정도가 다를 수 있으며, 두 기질과 반응물과의 결합 정도가 상이하여 radical 제거 능력에도 차이가 생기는 것으로 사료된다(36).

ABTS radical 소거능(Table 5)은 진공동결건조 오미자가 $93.85 \%$ 로 가장 높은 활성을 나타내었으며, 원적외선건조 오미자 $87.92 \%$, 열풍건조 오미자 $85.91 \%$ 순으로 나타났으 며, DPPH radical 소거능보다 높은 활성을 나타내었다. Cho 등(33)의 오미자 물 추출물과 $60 \%$ ethanol 추출물의 ABTS radical 소거능은 $96.6 \%, 97.0 \%$ 로 나타나 본 실험 결과에 비해 높은 값을 나타내었고, Choi 등(37)은 오미자 $99.5 \%$ 메탄올 추출물의 $\mathrm{ABTS}$ radical 소거능 측정 결과 $37.97 \sim 53.35 \%$ 로 보고하여 본 실험 결과 보다 낮은 값을 나타내었다. 이는 추출 용매와 농도, 시간 등에 의해 영향을 받는 것으로 생각된다.

\section{아질산염 소거능}

아질산염 소거작용은 체내외에서 효소작용에 의해 환원 된 nitrite가 amine류와 반응하여 발암물질인 nitrosamine을 생성하여 각종 중독을 유발하는 것으로 알려진 nitrite를 제거하여 발암을 억제하는 작용이다 $(38,39)$.

아질산염 소거능(Table 5)은 원적외선건조 오미자 $90.04 \%$, 열풍건조 오미자 $88.78 \%$, 진공동결건조 오미자 $82.58 \%$ 순으로 나타났다. Jeon 등(40)의 연구에서는 $\mathrm{pH} 1.2$ 에서 ethanol 추출물의 경우 76 83\%의 소거능을 보고하였 으며, Jung 등(41)은 $\mathrm{pH} 1.2$ 에서 ethanol 추출물 $91.9 \%$, 열수 추출물 $57.4 \%$ 로 보고하여 시료의 처리 방법이나 추출 조건 에 따라 값의 차이가 나타나는 것으로 생각된다.

원적외선건조에서는 아질산염 소거능이 가장 높은 값을 나타내었는데, 이는 건조 과정 중 열에 의한 갈변반응으로 생성된 melanoidine에 의한 것으로 생각된다. 식품의 가공, 저장 및 조리 중에 용이하게 생성되는 Maillard 반응 생성물 은 아질산염 소거능을 나타내는 것으로 알려져 있는데(42), Kato 등(18)의 연구에서는 Maillard 반응 생성물인 melanoidin 이 nitrosamine의 생성을 저해하는데 효과가 있는 것으로 보고한 바 있다. 본 실험에서도 갈변반응이 일어나기 쉬운 원적외선 건조와 열풍건조에서 아질산염 소거능이 높은 것으로 나타나 아질산염 소거능을 증가시키는 화합물에 갈변 반응 생성물인 melanoidine이 포함되어 있을 것으로 
생각된다.

\section{총 페놀 함량}

식물성 식품에는 많은 폴리페놀성 분자들이 함유되어 있는데 이러한 페놀성 화합물은 체내에서 항산화, 항비만 및 항염증 등과 같은 생리활성을 가지고 있는 것으로 알려 져 있다(43). 총 폴리페놀 함량은 폴리페놀의 산화 환원반응 을 응용한 것으로 페놀성 물질인 phosphomolybdic acid와 반응하여 청색을 나타내는 원리를 이용하였다(44).

총 페놀 함량 측정결과(Table 6) 진공동결건조 오미자 $1663.70 \mathrm{mg} / 100 \mathrm{~g}$, 열풍건조 오미자 $1021.19 \mathrm{mg} / 100 \mathrm{~g}$, 원적 외선건조 오미자 $1001.25 \mathrm{mg} / 100 \mathrm{~g}$ 순으로 나타났다. Chang 과 $\operatorname{Kim}(45)$, Chung 등(46)의 연구에서도 열풍건조보다 동 결건조 시료에서 총 페놀 함량이 높은 것으로 보고하여 본 실험과 유사한 경향을 나타내었다. Wink (47)에 따르면 일반적으로 페놀성 물질의 경우 수용성과 불용성으로 구분 이 되며 삼투압 및 열적 처리시 일정 유용성분 또한 함께 빠져나갈 수 있는 것으로 보고되어 있는데 본 실험의 열풍 건조 및 원적외선건조 오미자가 열처리에 의해 유용성분의 유출에 따른 손실로 총페놀 함량이 낮게 나타난 것으로 생각된다. Kim과 Park(48), Jeon 등(49)에 의해 보고된 오미 자 에탄올 추출물의 총 페놀 함량은 각각 $1009.4 \mathrm{mg} / 100 \mathrm{~g}$, $953 \mathrm{mg} / 100 \mathrm{~g}$ 으로 보고하여 본 실험과 비슷한 값을 나타내 었고, Cho 등(33)은 $60 \%$ 에탄올 추출물의 총 페놀 함량을 $630 \mathrm{mg} / 100 \mathrm{~g}$ 로 보고하여, 본 실험보다 낮은 값을 나타내었 다. Park 등(7)은 동결 및 열풍건조 오미자의 총 페놀함량은 에탄올 $(50,70 \%)$ 추출물 > 에탄올 $(99 \%)$ 추출물 > 열수 추출 물 순으로 높게 나타나 에탄올이 물과 혼합할 경우 총 페놀 함량에 크게 영향을 미치는 것으로 나타났다고 보고하였는 데, 에탄올 함량에 따른 차이가 실험 결과에 영향을 끼친 것으로 생각된다.

Table 6. Total phenol, total flavonoid and total tannin content of different dry condition of Omija (Schizandra chinesis Bailon)

\begin{tabular}{cccc} 
& & & $(\mathrm{mg} / 100 \mathrm{~g})$ \\
\hline Sample & Total phenol & Total flavonoid & Total tannin \\
\hline $\begin{array}{c}\text { Hot-air drying } \\
\begin{array}{c}\text { Far-infrared } \\
\text { radiation drying }\end{array}\end{array}$ & $1021.19 \pm 86.31^{\mathrm{b}}$ & $224.02 \pm 9.48^{\mathrm{b}}$ & $417.45 \pm 26.17^{\mathrm{b}}$ \\
$\begin{array}{c}\text { Vacuum freez } \\
\text { drying }\end{array}$ & $1663.70 \pm 51.06^{\mathrm{a}}$ & $351.35 \pm 57.46^{\mathrm{a}}$ & $514.04 \pm 24.88^{\mathrm{a}}$ \\
\hline
\end{tabular}

${ }^{1)}$ Quoted values are the mean \pm standard deviation of triplicate experiments.

${ }^{a-c}$ Values with different superscripts in a row are significantly different $(\mathrm{p}<0.05)$.

\section{총 플라보노이드 함량}

플라보노이드는 식물에 의해 합성된 페놀성 화합물로 노란색, 담황색 및 적자색을 띄는 색소 화합물로서 식물 중에는 대부분 당과 결합된 배당체(glycoside) 형태로 존재
한다. 이들은 활성 산소종을 효과적으로 제거하여 심장질 환, 항암 및 항염 등의 생리기능을 가지는 것으로 알려져 있다(50,51).

총 플라보노이드 함량(Table 6)은 진공동결건조 오미자 $351.35 \mathrm{mg} / 100 \mathrm{~g}$, 원적외선건조 오미자 $227.51 \mathrm{mg} / 100 \mathrm{~g}$, 열풍건조 오미자 $224.02 \mathrm{mg} / 100 \mathrm{~g}$ 로 순으로 함유되어 있었 고, 전체적으로 총 페놀 함량보다는 낮은 값을 나타내었다. 진공동결건조 오미자는 총플라보노이드 및 총페놀 함량에 서 가장 높은 값을 나타내어 다른 건조 방법에 비해 항산화 효과가 높은 것으로 나타났다.

Kim과 Choi(52)의 연구에서는 증류수를 이용한 오미자 추출물의 플라보노이드 함량을 $197.8 \mathrm{mg} / 100 \mathrm{~g}$ 으로 보고하 여 본 실험보다 낮은 값을 나타내었는데, 이는 시료의 추출 용매의 차이에 의한 것으로 생각된다.

\section{총 탄닌 함량}

Tannin은 차의 가장 중요한 성분의 하나로 차의 맛, 향기 및 색에 깊이 관여하며, 여러 가지 생리작용을 가지는 성분 으로 알려져 있다(52).

탄닌 함량(Table 6)은 진공동결건조 오미자 514.04 $\mathrm{mg} / 100 \mathrm{~g}$, 원적외선건조 오미자 $421.18 \mathrm{mg} / 100 \mathrm{~g}$, 열풍건조 오미자 $417.45 \mathrm{mg} / 100 \mathrm{~g}$ 으로 나타났으며, 총 페놀 함량에 비해서는 낮은 값을 나타내었지만, 총 플라보노이드 함량 보다는 전체적으로 높은 값을 나타내었다.

$\mathrm{Oh}$ 등(4)의 연구에서는 오미자 물 추출물과 $50 \%$ 에탄올 추출물에서의 탄닌 함량은 각각 $278.2 \mathrm{mg} / 100 \mathrm{~g}, 949.3$ $\mathrm{mg} / 100 \mathrm{~g}$ 로 보고하여 본 실험 결과와는 차이를 나타내었다.

$\operatorname{Kim}$ 과 $\operatorname{Kim}(53)$ 은 물과 $70 \%$ 에탄올 추출시 동결건조에 비해 오븐건조와 분무건조 시 낮은 값을 나타내었고, 이는 고온처리에 의하여 탄닌 성분의 변성이 일어난 것으로 생각 된다고 하였다. 본 실험에서도 진공동결건조 오미자가 원 적외선건조와 열풍건조 오미자에 비해 높은 값을 나타내었 는데, 이는 오미자가 열에 의한 갈색화 반응으로 인하여 폴리페놀 화합물이 형성됨으로써 총 탄닌의 함량에 영향을 끼친 것으로 생각된다.

\section{요 약}

본 연구에서는 건조방법(열풍건조, 원적외선건조, 진공 동결건조)을 달리한 오미자의 품질 특성 및 항산화 효과를 비교 검토하여 고품질의 건조 오미자를 얻기 위한 기초 자료를 제시하고자 하였다. 수분 함량 및 수분활성도(Aw) 는 열풍건조 > 원적외선건조 > 진공동결건조 순으로 나타 났다. $\mathrm{pH}$ 는 건조방법에 따른 차이는 없었고, 당도는 6.60 ${ }^{\circ} \mathrm{Brix}$ 로 진공동결건조 오미자가 가장 높은 값을 나타내었 다. 탁도는 열풍건조 $8.24 \mathrm{~T} \%$, 원적외선건조 $0.32 \mathrm{~T} \%$, 진공 
동결건조 $71.85 \mathrm{~T} \%$ 를 나타내었으며, 색도 $\mathrm{L}, \mathrm{a}, \mathrm{b}$ 는 진공동 결건조가 다른 건조방법에 비해 높게 나타났다. 유리당 함 량은 glucose $>$ fructose $>$ sucrose 순으로 나타내었고, 총 유리당 함량은 진공동결건조 오미자가 $5.01 \mathrm{~g} / 100 \mathrm{~g}$ 으로 가장 높은 값을 나타내었다. 항산화 활성에서 $\mathrm{DPPH}$ radical 소거능, $\mathrm{ABTS}$ radical 소거능에서는 각각 진공동결건조 오 미자가 $88.68 \%, 93.85 \%$ 로 가장 높은 활성을 나타내었다. 반면 아질산염 소거능은 원적외선건조 오미자가 $90.04 \%$ 로 가장 높은 값을 나타내었고, 열풍건조 오미자는 $88.78 \%$, 진공동결건조 오미자가 $82.58 \%$ 의 순으로 활성을 나타내었 다. 총페놀, 총 플라보노이드, 총 탄닌 함량에서 진공동결건 조 오미자가 $1633.70 \mathrm{mg} / 100 \mathrm{~g}, 351.35 \mathrm{mg} / 100 \mathrm{~g}, 514.04$ $\mathrm{mg} / 100 \mathrm{~g}$ 으로 가장 높은 값을 나타내었다. 이상의 결과에서 건조방법은 오미자의 품질특성 및 항산화 효과에 유의적인 영향을 주는 것으로 나타났으며, 진공동결건조 오미자는 다른 건조방법에 비해 높은 품질 특성과 항산화 효과를 나타내었다.

\section{감사의 글}

본 연구는 농촌진흥청 15 대 아젠다과제(PJ008490)의 연 구비 지원에 의해 수행되었으며, 이에 감사드립니다.

이 논문은 2012학년도 경북대학교 학술연구비에 의하여 연구되었음

\section{References}

1. Lee JS, Lee MG, Lee SW (1989) A study on the general components and minerals in parts of Omija (Schizandra chinensis Baillon). Korean J Dietary Culture, 4, 173-176

2. Lee JS, Lee SW (1990) Effect of water extracts in Omija(Schizndra chinenesis Baillon) on alcohol metabolism. Korean J Dietary Culture, 5, 259-263

3. Mok CK (2005) Quality characteristics of instant tea prepared from spray-dried Omija (Schizandra chinensis Baillon) extract/grape juice mixture. Food Eng Prog, 9, 226-230

4. Oh SL, Kim SS, Min BY, Chung DH (1990) Composition of free sugars, free amino acid, non-volatile organic acids and tannins in the extracts of $L$ chinesis M., $A$ acutiloba K., S. chinensis B. and $A$ sessilifforum S. Korean J Food Sci Technol, 22, 76-81

5. Kim DG, Kim MB, Kim H, Park JH, Im JP, Hong SH (2005) Herb medicinal pharmacognosy. Shinill Books, Seoul, Korea, p 407
6. Kim OC, Jang HJ (1994) Volatile components of Schizandra chinensis Baillon. Korean J Agric Biotech, 39, 30-36

7. Park EJ, Ahn JJ, Kim JS, Kwon JH (2013) Antioxidant activities in freeze-dried and hot air-dried Schizandra fruit (Schizandra chinensis Baillon) at different microwaveasssisted extraction conditions. Korean J Food Sci Technol, 45, 667-674

8. Kozempel JF, Sullivan JC, Craig JR, Konstance KP (1989) A research note-explosion puffing of fruits and vegetables. J Food Sci, 54, 772-775

9. Youn KS, Cho YH (1998) The quality characteristics of dried kiwifruit using different drying methods. Food Eng Prog, 2, 49-54

10. Choi JH, Im JS, Oh DH (2006) Quality enhancement of vaccum packaged waxy corns by far infrared ray drying. J Korean Soc Food Sci Nutr, 35, 635-640

11. Park EJ, Ahn JJ, Kwon JH (2013) Effect of reflux conditions on extraction properties and antioxidant activity of freeze dried-Schisandra chinensis. Korean J Food Sci Technol, 45, 550 556

12. Choi YH, Cheong YK, Park KH, Park MS (2001) Changes of quality in dried Omija(Schizandra chinensis Baillon) during storage. Korean J Postharvest Sci Technol, 8, 351-355

13. Kim KS, Song JS, Bang JK (2000) Changes in volatile compounds of Schizandra chinensis fruits according to drying and extracting methods. Korean J Medicinal Crop Sci, 3, 49-57

14. AOAC (1990) Official Methods of Analysis 2nd ed. Association of Official Analytical Chemists, Washington DC. $\mathrm{p} 8-20$.

15. Wilson AM, Work TM (1981) HPLC determination of fructose, glucose and sucrose in potatose. J Food Sci, 46, 300-301

16. Blios MS (1958) Antioxidant determinations by the use of a stable free radical. Nature, 181, 1199-1200

17. Thaipong K, Boonprakob U, Crosby K, Cisneros-Zevallos L, Byrne DH (2006) Comparison of ABTS, DPPH, FRAP, and ORAC assays for estimating antioxidant activity from guava fruit extracts. J Food Comp Anal, 19, 669-675

18. Kato H, Lee IE, Chyuen NV, Kim SB, Hayase F (1987) Inhibitory of nitrosamine formation by nondialyzble melanoidins. Agric Biol Chem, 51, 1333-1338

19. Gutfinger T (1958) Polyphenols in olive oils. J Am Oil Chem Soc, 58, 966-968 
20. NFRI (1990) Manuals of quality characteristic analysis for food quality evaluation. National Food Research Institute, Skuba, Japan, p 61

21. Paaver U, Matto V, Raal A (2010) Total tannin content in distinct Quercus robur L. galls. J Med Plants Res, 4, 702-705

22. Jung GT, Ju IO, Choi JS (1998) Studies on drying and preservation of Omija (Shizandra chinensis BAILL.). Korean J Postharvest Sci Technol, 5, 217-223

23. Kim PJ, Lee JC, Ko KH, Lee CH (2004) Effects of drying and extraction conditions on the chemical composition of water extract of Lycium chinense Miller. Food Eng Prog, 8, 105-110

24. Choi HY, Mim MN, Lee KH (1973) Non-enzymatic browning reactions in dried squid stored at different water activities. Bull Korean Fish Soc, 6, 97-100

25. Han SB, Lee JH, Lee KH (1973) Non-enzymatic browning reactions in dried achovy when stored at different water activites. Bull Korean Fish Soc, 6, 37-43

26. Kim YJ, Lee KS, Kim MY, Kim GR, Chung HS, Park HJ, Kim MO, Kwon JH (2009) Physicochemical and organoleptic qualities of sliced-dried persimmons as affected by drying methods. Korean J Food Sci Technol, 41, 64-68

27. Kim YJ, Lee YG, Choi YW, Kim YC (2008) Effects of drying conditions on the profile of volatile terpenoid and colour of Schizandra Fruit (Schizandra Chinensis fruchis). J Life Sci, 18, 1066-1071

28. Yang CST, Atallah WA (1985) Effect of four drying methods on the quality of intermediate moisture lowbush blueberries. J Food Sci, 50, 1233-1237

29. Kim HK, Na GM, Ye SH, Han HS (2004) Extraction characteristics and antioxidative activity fo Schiznadra chinensis extarcts. Korean J Food Culture, 19, 484-490

30. Ancerewicz J, Migliavacca E, Carrupt PA, Testa B, Bree F, Zini R, Tillement JP, Labidalle S, Guyot D, Chauvet-Monges AM, Crevat A, Le Ridant A (1998) Structure-property relationships of trimetazidine derivatives and model compounds as potential antioxidants. Free Radic Biol Med, 25, 113-120

31. Choi Y, Lee SM, Chun J, Lee HB, Lee J (2006) Influence of heat treatment on the antioxidant activities and polyphenolic compounds of Shiitake (Lentinus edodes) mushroom. Food Chem, 99, 381-387

32. Kim JS, Choi SY (2008) Physicochemical properties and antioxidative activities of Omija (Schizandra chinensis Bailon). Korean J Food Nutr, 21, 35-42
33. Cho YJ, Ju IS, Kim BC, Lee WS, Kim MJ, Lee BG, An BJ, Kim JH, Kwon OJ (2007) Biological activity of omija (Schizandra chinensis Baillon) extracts. J Korean Soc Appl Biol Chem, 50, 198-203

34. Chang Y, Kim J (2011) Effects of pretreatment and drying methods on the quality and physiological activities of garlic powders. J Korean Soc Food Sci Nutr, 40, 1680-1687

35. Roberty R, Anna P, Anna P, Catherine RE, Min P, Nicoletta P (1999) Antioxidant activity applying an improved ABTS radical cation decolorization assay. Free Radical Bio Med, 26, 1231-1237

36. Yu JS, Jung HS, Woo JH, Jang HD, Lee CH (2008) Antioxidant effect of extracts obtained from four aster species native to Korea. Korean J Plant Res, 21, 52-59

37. Choi EJ, Kim SH, Shim SH, Chung HJ, Bang WS (2012) Antioxidative activity of the $\mathrm{n}$-hexane fractions from Spatholobus suberectus (SS), Scutellsria barbata (SB), Psoralea corylifolia (PC), Curcuma zedoaria (CZ), Schisandra chinensis (SC), and Corydalis turtschaninovii (CT). Korean J Food Sci Technol, 44, 493-497

38. Peter FS (1975) The toxicology of nitrate and N-nitroso compounds. J Sci Food Agric, 26, 1761-1770

39. Roralds W (1975) Naturally occurring nitrite in food. J Japan Soc Food Agric, 26, 1735-1742

40. Jeon TW, Jo C, Kim KH, Byun MW (2002) Inhibitory effect on tyrosinase and xanthine oxidase, and nitrite scavenging activities of Schizandrae fructus extract by gamma irradiation. Kroean J Food Preserv, 9, 369-374

41. Jung GT, Ju IO, Choi JS, Hong JS (2000) The antioxidative, antimicrobial and nitrite scavenging effects of Schizandra chinensis Ruprecht (Omija) seed. Kroean J Food Sci Technol, 32, 928-935

42. Kim SB, Do JR, Lee YW, Gu YS, Kim CN, Park YH (1990) Nitrite-scavenging effects of roasted-barley extracts according to processing conditions. Korean $\mathbf{J}$ Food Sci Technol, 22, 748-752

43. Lee YJ, Han OT, Choi HS, Lee BY, Chung HJ, Lee $\mathrm{OH}$ (2013) Antioxidant and anti-adipogenic effects of PineXol $^{\circledR}$. Korean J Food Sci Technol, 45, 97-103

44. Ainsworth EA, Gillespie KM (2007) Estimation of total phenolic content and other oxidation substrates in plant tissues using Folin-Ciocalteu reagent. Nat Protoc, 2, 875-877

45. Chang YE, Kim JS (2011) Effects of pretreatment and drying methods on the quality and physiological activities of garlic powders. J Korean Soc Food Sci Nutr, 40, 
1680-1687

46. Chung HS, Kim IH, Kim SH, Lee JH (2013) Antioxidant properties of Pinus koraiensis needle powder extracts as influenced by drying methods. Food Eng Prog, 17, 396-400

47. Wink M (1997) Compartmentation of secondary metabolites and xenobiotics in plant vacuoles. Adv Botan Res, 25, 141-169

48. Kim MJ, Park EJ (2010) Antioxidative and antigenotoxic effect of Omija (Schizandra chinensis B.) extracted with various solvent. J Korean Soc Food Sci Nutr, 39, 487-493

49. Jeon YH, Kil JH, Lim SM, Kim MH, Kim MR (2008) Analysis of antioxidative activity and antimutagenic effect of ethanol extract from Schizandra chinensis Baillon. J East Asian Soc Dietary Life, 18, 746-752

50. Williams RJ, Spencer JP, Rice-Evans C (2004) Flavonoids : antioxidants or signaling molecules? Free Radic Biol Med, 36, 838-849

51. Jeong HY (1991) Aging ·free radical·arteriosclerosis. J Life Science, 1, 2-14

52. Nakagawa M, Amano I (1974) Evaluation method of green tea grade by nitrogen analysis. Nippon Shokuhin Kogyo Gakkaishi, 21, 57-63

53. Kim NM, Kim DH (2000) Quality change of cinnamon extract prepared with various drying methods. Korean J Food Nutr, 13, 152-157

(접수 2014년 4월 10일 수정 2014년 6월 10일 채택 2014년 6월 19일) 